\title{
The Research on The Ideological and Political Work of Ideology in The New Media Era Guided by Marx
}

\author{
Yu He \\ Marx School of Marxism, Sichuan Agricultural University ,Ya'an of Sichuan province 625014
}

\begin{abstract}
Keywords: New media; Marx doctrine; News view; Ideology; Public opinion guidance
Abstract. In today's era, the rapid development of new media in the ideological field of the growing influence of the rich in the dissemination of information at the same time, but also changed people's reading habits. The new media bring convenience, which can bring the audience to some dragons and fishes jumbled together, and negative information, resulting in adverse effects on public opinion. Therefore, it is necessary to adhere to the guiding role of Marx's ideas in the propaganda and ideological work. This paper summarizes the opportunities and challenges brought by new media, and analyzes the significance of the concept on the Marx doctrine of public opinion guidance from the needs of the times and occupation need several aspects, and how to insist on Marx's role in guiding public opinion provides several methods.
\end{abstract}

\section{Introduction}

In the process of news communication, to promote the good and the beautiful, attacked the evil, this is a universally recognized truth, needless to say. However, in the diversification of the channels of news media, some media have trampled on the truth and crossed the moral bottom line, so that some reports of moral anomie, the wrong guide people's thinking. The field of ideology is complicated and fierce dispute, as early as August 19, 2013, general secretary Xi Jinping on the national publicity and ideological work in the meeting clearly pointed out: dare to distort history national history, to demonize the party leader, deny the wrong thought leadership of the Communist Party, China sword attack Chinese socialist system, in order to resist the penetration of Western ideology and, for those who attack the leadership of the party, attack the socialist system and distort history national history, false speech, all newspapers and books, the platform Forum, meeting, film and television, radio and stage theater can provide space for the all digital newspapers, mobile TV, mobile phone media, mobile phone SMS, WeChat, blog micro blog, forums, podcasts, and other new media can provide convenient. February 19, 2016, Xi Jinping, general secretary of the press and public opinion at the forum stressed the importance of strengthening the ideology of the Marxist ideology of the forum again in. In the face of the slander and impact of noise, the propaganda and ideological work in the new media era must unswervingly adhere to the concept of Marx.

\section{Opportunities and challenges brought by new media}

As everyone knows, the traditional media mainly refers to radio and television, magazines, newspapers, radio and other media, with the development of Internet technology, new media gradually appeared in people's field of vision, and was called after the four traditional media "the fifth media". The so-called new media, which is produced in the new technical support system of mobile phone SMS, network, digital TV, touch media digital media, relative to traditional media, new media is a changing concept. In a broad sense, any computer related, which can be said to be the new media. Now the new media which is generally appear on the basis of the telecommunications network in the form of media, such as WeChat, QQ and Email of online communication platform, or like micro-blog, Renren, facebook circle of friends of the online exchange etc. The emergence of new media, the traditional media has caused an unprecedented impact, but this impact is not entirely negative, it can be said that opportunities and challenges coexist.

First, the impact of new media on traditional media is an opportunity. Because whether it is the traditional media, or the new media, in fact, the core content is the same, that is, to report news, 
express opinions, guide public opinion, the key is who can do better. Who do better, who will have more audience and greater influence, thus forming a mutual promotion, healthy competition. The new media has the individuality, the audience, the news release time and other characteristics, greatly cater to the preferences of the audience, there is no doubt that the new media information dissemination way unique in the subtle habits of the audience contact and contact behavior has great influence. People can better and more quickly know all kinds of news happens, no limit of time and space, a strong force in the Internet, spread about the human consciousness in a short period of time, which have a certain effect of public opinion. Traditional media in the dissemination of speed and coverage, although there is a lack of in-depth reporting, creativity and other aspects of the comparative advantage, which provides an opportunity for both sides of the media workers complement each other. In addition, the new media is our party in the network an important propaganda tool, shouldering the Marx Lenin doctrine, Mao Zedong thought, Deng Xiaoping theory and the important thought of "Three Represents", scientific outlook on development and comrade Xi Jinping series of important speech China armed Communist Party's important duty. As the guide of public opinion in the network media, publicity to the well "the mouthpiece of the party", safeguarding national interests and interests of the people, which is another way to show his ability.

Secondly, the rapid rise of new media, there are enormous challenges. The tide of market economy and the new media of the press is relatively large impact, coupled with social network without borders, they produced a lot of false, ominous, vulgar content, occult network spread to hundreds of millions of Internet users can easily make a detour, which avoids the local government regulation and control. Some media workers have lost the bottom line of professional ethics, false news hype false propaganda. In the hearts of these media, only to find the selling point of the so-called sensation, and political awareness, the overall situation, as well as the correct guidance of public opinion, which are thrown into the back. False reports are produced in order to achieve a certain purpose, and the use of false information, in order to deceive the public or a public opinion, and which can not truly reflect the original objective things.

For example, in 2014 of December, online crazy pass, Lanzhou, Zhang Yelu chased hair halo little girl video in pedestrian street, so that people have questioned the attitude of urban management law enforcement, seriously affecting the credibility of the government. Then the official survey of the Lanzhou hit chased attack "results released: November 15, 2014, a woman in the pedestrian street along the flyers, the urban management department staff discourage invalid after the temporary one leaflet detained two women and then follow the staff came to the duty room, swearing abuse, and even make impertinent remarks, encourage male friends the inspectors tearing, beaten. Receiving the alarm, the police rushed to the scene in the stop message invalid case fired warning shots, which prevents malignant development situation. This false news broke out, resulting in a huge public opinion effect, resulting in a very bad social impact.

As of January 4, 2016, the Henan Provincial Public Security Bureau official micro-blog rumor network "Henan college students marry mother" incident. Since 2013, a similar article relates to different places, using the same pictures, the same plot, the same text in micro-blog, WeChat, QQ and other media channels wantonly spread " 21 year old handsome students marry a 55 year old divorced middle-aged aunt in a hotel in Henan, the first department of false news and groom college classmate's mother" behind, attract public attention, but in order to sell some expensive skin care products, cosmetic treatment propaganda. Such news, fabricated, distorted facts, seriously undermine the social atmosphere, contrary to the practice of socialist core values.

Therefore, the use of new media technology is a "double-edged sword", not only to the media workers to provide opportunities, but also challenges. How in the new media era, to ensure the objectivity and authenticity of news and public service purposes, grasp the correct guidance of public opinion, to establish the correct values, provide positive energy, to create a good social atmosphere, each people must face the problem of media. In order to solve this problem and meet the challenge in the field of ideology, we must adhere to the concept of Marx's propaganda and ideological work. 


\section{Why should we adhere to the correct guidance of public opinion of Marx's ideas in the new media era}

Sticking to Marx's concept of journalism is the guarantee for the healthy development of socialist Journalism. Socialist journalism is an important position of ideological work of the party, leaving the correct guidance of Marx doctrine, China journalism will lose the direction. In February 19, 2016, the general secretary Xi Jinping chaired a press conference that the working party meeting, in-depth study of Marx's philosophy, which is the key to the news media workers to do a good job of party press work. Only to ensure that the guiding position of the Marx doctrine in the party's journalism, to dominate the news public opinion firmly in the hands of the party and the people loyal to the media, in order to ensure that our party always gratified cause toward the correct path.

The age of the Internet, creating new media information are many and varied, which in addition to containing valuable positive political affairs, entertainment and culture, there are many vulgar, negative, negative information, because the transmission speed, the supervising of the government departments can not timely response, short time, negative the news easily swept the entire network, causing negative impact of public opinion. At present, China is facing a serious and complex, fast changing international situation. On the one hand, the western powers stepped up the implementation of China's westernization and differentiation. Western media use strong position, with the characteristics of the new media widely spread to the world to promote western values. In the mainstream media in some western countries, only $10 \%$ of China's positive and objective reports, and the other is the false and distorted reports of the attack, which is $90 \%$. Around the major international and domestic emergencies as well as the introduction of some important policies in China, distorted and attacked, inciting discontent. On the other hand, the domestic situation is also facing major challenges, ideological and cultural values of multiple. In the field of ideology in China, there has been a question of Marx's guiding position, and the news media also has a tendency to pursue the Western news values, and deny the erroneous tendency of Marx. Some media even distorted understanding of China's news system, that there is no freedom of the press in China, wanton propaganda media should be a social device, the media is the fourth power".

Faced with this situation, the news media as the mouthpiece of the party and the people, to firmly grasp the correct guidance of public opinion, guiding the people with correct public opinion. This requires the media to establish the correct values in the process of news work, thoroughly implement the concept of the Marx doctrine, with the right ideas to guide the work of the maintenance of the network world is pure, to ensure the healthy development of socialist journalism.

Marx's idea is the guiding light of the news media workers in the new media era. Journalism is an important part of the cause of the party and has a very important position. Under the current situation, the emergence of public opinion mainly depends on the new media. As a new media workers, shouldering the major responsibility, affecting the guidance of public opinion.

Comrade Jiang Zemin once pointed out: "the correct guidance of public opinion is the blessing of the party and the people." Comrade Hu Jintao pointed out: "the correct guidance of public opinion, social stability, people's unity, prosperity, which is the party and the people's blessing." In February 19, 2016, comrade Xi Jinping stressed: "the party of the news public opinion work is an important task of the party, which is governing the country, regarded the event, to adapt to the development of domestic and international situation, starting from the overall work of the party's hold position, adhere to the party's leadership, adhere to the correct political direction, adhere to the people-centered job oriented respect, the news dissemination rule, innovation methods, and effectively improve the party's public opinion propagation force, guiding force, influence, credibility." This opinion is correct or not, which is an important indicator of the new media workers party spirit principle and the strength of the ideological and political qualities, one of the occupation ethics is necessary.

After a long time of practice, the party's news media team has become a strong political sense, worthy of trust. But at the same time should also pay attention to, especially in the team in the new media staff in the overall ideological quality special aspects there is a certain gap, especially some journalist Marx's consciousness is relatively weak. Most of the new media is the new era of young 
people, many of whom have just graduated from college students, and even college students. They lack the study and practice of the system of Marx's philosophy, keenly aware of lack of journalism of our party, the ever-changing society, the international situation lacks the political resolution, resulting in deviation or error at work. Therefore, it is urgent to improve the overall quality of the media workers with Marx's ideas.

In the new media era of Internet technology, the Marx doctrine still has profound guiding significance. Marx's philosophy is the scientific methodology, which is the foundation of a large number of journalism practice of a scientific conclusion is based on a scientific system to keep pace with the times, continuous development, even in the new media era, Marx's idea still have an unshakable position.

General secretary Xi Jinping stressed: "to carry out Marx's philosophy of education, guide the majority of media workers do rye communicators, the policies of the party of the time and record, the promoter of social progress and justice." This is the clear requirements of the general secretary for the majority of journalists, only firmly establish Marx's philosophy, consciously resist the Western so-called "independent media", "absolute freedom news" and so on the wrong point of view, to live up to the trust of the party and the people to give the more effectively play a leading social cohesion, and promote the development of the role of. In order to carry out the propaganda and ideological work in accordance with the requirements of the Marx doctrine, the new media workers should take the concept of the Marxism as the criterion, and in accordance with the requirements of the concept of the Marx doctrine.

The idea of Marx is the banner of the correct guidance of the audience in the new media era. Compared with the traditional media, the audience of the new media is younger, among them, the big and middle school students are the main force. Their ideology will affect the ideology of the public. They have thought, ability, independent, in the field of new media to express their opinions, each one airs his own views, opinions and even discontent. But because the network virtual world and the "freedom of speech", extremely easy to cause the students to false propaganda, vulgar information of indulgence, express wrong ideas and thoughts, causing negative social public opinion, lead to distorted ideology, deviate from the correct track of thought.

Therefore, the majority of young students need a correct ideological guidance, teachers responsibility. The teacher is the young students of the road of life guide, leading to its correct ideology plays a vital role, therefore, teachers must be in the Marx doctrine under the guidance of imparting knowledge, shaping the spirit of the character, contain errors and negative ideology production. In addition, newspaper, journal of the major institutions have spread the news, information interaction, play spread knowledge, promote the academic research and promote the important role of education reform, this period also need to edit the reporters engaged in propaganda and ideological work of colleges and universities in Marx socialist prison thinking, theory and practice combination widely spread, effectively eliminate the adverse effects, guiding students to set up correct views.

\section{How to adhere to the correct guiding role of public opinion in Marx 's view on Journalism}

Marx's view of journalism is the general view of Marx's news and news communication activities. Its core is a series of basic views on the nature of the work, the working principle and the working principle of the proletarian political party journalism of Marx. Under the new situation of the rapid development of the new media, the media workers should adhere to the following principles in order to adhere to the Marx doctrine of journalism.

Always adhere to the principle of party spirit. The fundamental principle is the principle of party spirit of Marxist news outlook of Marx. China is China people under the leadership of the Communist Party in power of socialist countries, the news media also serve proletariat, we insist on the principle of everything, are based on the principle of spirit, the nature of socialism. So in the news practice, we must firmly grasp the correct direction of public opinion of the media, journalists asked to strengthen the study of political theory to firmly establish political awareness and sense of responsibility, the 
primary position of publicity and the correct guidance of public opinion in their work; secondly, the news should always alert their compliance with the press, saying "iron law" said: "there is no restricted area, the propaganda discipline". As a new media, but also know in a quasi rich also should have high political quality, not only to be responsible for the work of the party and state, but also to be responsible for the broad masses of people will always uphold the principles of objectivity, grasp the scale on sensitive topics, such as hot politics, and avoid emotional act on impulse. Have the iron shoulders moral, hand in "social responsibility and moral integrity, dedication to the ideological, artistic taste for social news works. To achieve a good social effect to test the success of the news work, always put the social benefits in the first place. At present, a large number of new media audience, news reports will spread quickly in a short period of time and have a certain public opinion effect. Therefore, to take into account the impact of all aspects of the news, can not have the slightest chance. This requires the time the media workers lead themselves to the principle of party spirit, with advanced Marxist news outlook of Marx armed themselves, guiding the society the correct direction of public opinion.

Always adhere to the principle of serving the people. The Communist Party of China represents the fundamental interests of the overwhelming majority of the people, the party's ideas, programs, policies, principles are to serve the people, reflecting the people's most fundamental aspirations and requirements. This determines the process of news media propaganda of the party's political news, which is a reflection of the broad masses of the people from the heart of the whole.

In the course of work, the new media workers must establish the idea of serving the people wholeheartedly. It is the bounden duty of journalists to report the contribution of the people in the socialist cause. In this process, it should always be in close contact with the masses, the masses of life, the interests of the masses of the people to the reaction, always put the people's voice and vision in the first place, the opinions of the masses as the real test work, to the satisfaction of the masses as the basic standard of media work, to keep the people's main body status in journalism, the camera focused more on the real life of the masses, the masses of the people to put more space. We should also focus on guiding and improving the positive cultural quality of the people, but also to prevent the tendency to cater to the vulgar tendency. Only in this way can we inspire the people to create a better life and create a harmonious socialist society.

Always adhere to the principle of truth seeking truth from facts. News reports should be objective and true. This kind of authenticity should be reflected in the details of the real, but also to show the essence of reality, from the direction of the development of things to see the essence. The choice of the news, not only to reflect the specific reality, micro reality, but also to reflect the overall development of the macro reality of society, to prevent mechanical, one-sided reports. With the wave of the Internet era, the release of news information is not the patent of the media staff, more and more people have the function of the release of the message. In this case, the task is not only the media news release, more important is to release the real effective information, the first time to convey news results to the audience, and guide the public opinion, to have a positive impact on people's ideology.

News reports from the authenticity, it is equivalent to the loss of life, the loss of the audience groups, and which even will have a negative impact on society, resulting in the masses of the people questioned and distrust of the government. So, under the new media development momentum, new media workers should always ensure the authenticity of reports, so any news sources are responsible for the rigorous verification, not exaggerated, do not hide, not to publish the directivity of speech, absolutely not allowed to engage in individualism, which will never allow the fabrication of false news mislead the public opinion, more don't allow no moral bottom line off speculation.

To enter the era of new media, new media network has almost become the most broad stage, open network platform, freedom does not mean that we can deny the existence of the news, the so-called news censorship is unreasonable. But "press freedom" by no means can wantonly "creation" news, which does not mean that can be fabricated, false propaganda negative news, abuse or false propaganda news will cause serious harm to the society, our party will also lead to reduced credibility. The new media workers should always adhere to the guiding role of Mark's public opinion, lead the field of consciousness, and contribute to the building of a harmonious and peaceful society. 


\section{Acknowledgment}

The study on Ideological and political education in Colleges and universities in Sichuan province (the special subject of Ideological and political theory course for young teachers) "path of Ideological and political theory course to improve students' legal consciousness and legal faith" (project number: SZQ2014067), at the same time by the Sichuan Agricultural University Association of Social Sciences project and Marx Institute of Double Plan "research" of socialist culture Chinese characteristics support.

\section{References}

[1] Baoshan Li. Marx consciously adhere to Marxism news view [J]. Seeking right,2013(16).

[2] Yanhua Kan, Kai Shang. Xi Jinping's Thought on the status and role of news and public opinion [J]. Deng Xiaoping research. 2016(06).

[3] Xiaohu Fang. Keeping the reporter's true nature as the duty and mission -- the fundamental pursuit of the news media workers under the new era [J]. Press. 2016(20).

[4] Dan Cai, Yongsheng Cai. On the construction of network culture from the perspective of Marx's view of news [J]. Guizhou social sciences. 2014(05).

[5] Jianqiang Wang. An analysis and Research on improving the quality of journalists [J]. Western radio and television. 2016(17).

[6] Lijuan Liu. The global consciousness and its foothold of Marx's view on journalism [J]. News outpost. 2016(02). 